\section{Nenad Milojević*}

\section{Optimal Banking and Other Financial Business for the Economic Growth of Serbia}

\begin{abstract}
The analysis of the banking / financial business impact on economic growth is a topic present in the world economy for centuries. In recent years, this topic has gained on importance in international economic circles. Actuality of the aforementioned impact particularly sparked the global economic crisis. In the focus of this paper is the impact of the level and speed of the financial development, particularly banking, on the economic growth in Serbia. Within the overall financial development, the focus is primarily dedicated to the banking business, which is still highly dominant segment of the financial sector in Serbia. We have conducted an analysis of the most important elements that have marked recent years' banking impact on the economic growth in Serbia. Actual characteristics of the aforementioned impact are also presented. Possible predictions of the banking / financial business movement in the future, as well as its impact on economic growth are presented in the paper. The focus is on determination of the optimal banking business volume for achieving sustainable economic growth in Serbia. The analysis presented in the paper indicate that there is significant potential for moderate and balanced growth of the banking / financial business in the medium term, which could make a significant contribution to the achievement of sustainable economic growth in Serbia, while providing financial stability. However, for the realization of this important and demanding goal, it is necessary to meet a significant number of factors and creation of the adequate conditions at the micro and macro level, essential for achieving the above mentioned aim.
\end{abstract}

Keywords: Banking Business, Financial Sector, Economic Growth, World Economic Crises

JEL Classification: G18, G21, G28, E32.
* Belgrade banking academy

- Faculty for banking,

insurance \& finance

E-mail:

nenad.m.milojevic@gmail.com 


\section{Introduction}

The impact of the financial sector and banking business on economic growth has been the actual topic in the world economic science for several centuries. We can say that this trend has intensified over recent years. One of the most interesting segments of this broad and complex topic is the question of finding the optimal financial intermediation for sustainable economic growth. We can say that the banking business takes the central place in the study of optimal financial intermediation. Besides the banking business volume analysis, adequate attention must be directed to the growth speed of the banking business, as one of the important elements for achieving sustainable economic growth.

One of the postulates of modern economics is that financial development is good for economic growth. The assumption is that in order to channel resources in the most effective way, economy needs financial intermediation between the lender and the borrower. The mentioned general opinions (with numerous modalities) were dominating for a long time in the global economic literature.

On the other hand, in recent years (especially after the start of the global economic crisis), opinions are expressed that the financial development is favorable for the economic growth, but to a certain extent, after which it starts to be a burden for future economic growth. In fact, especially the most developed economies of the world, with the most developed financial systems, have faced with a significant drop in gross domestic product (GDP) and the serious consequences of the crisis, compared to many less developed economies and their financial systems.

Another element that is very interesting for the relationship of the financial development and GDP, is the speed of the financial sector development. Fast growing economy finance and the appearance of a credit boom may jeopardize sustainable economic growth, financial stability, and overall macroeconomic stability.

The research conducted in this paper was primarily focused on the analysis of the impact of the financial / banking development level and speed, on the economic growth in Serbia. Within the overall financial development, the focus is primarily dedicated to the banking business, which is still highly dominant segment of the financial sector in Serbia. By analyzing the development of the banking sector in Serbia (BSS), starting from year 2000 to date, we can conclude that there has been significant progress, modernization, rapid growth and convergence to the international/European standards of the banking business. During this period, within the financial sector, commercial banks have made the most substantial progress and convincingly dominate in the sector. 
The rest of the financial sector of Serbia (FSS): insurance companies, voluntary pension funds, financial leasing, broker-dealer companies and investment fund management companies, have also made significant progress and are trying to follow the BSS. However, reduction of the dominance of banks in the financial sector is still not in sight.

We can say that the rapid growth of the BSS is quite understandable, having in mind the backlog that the entire Serbian economy had at the beginning of XXI century in comparison to other European countries in transition, which had begun their reforms earlier and have not been affected by sanctions, wars and such a strong economic crisis during 1990 . The analysis indicates that a relatively rapid growth of the BSS in the previous period did not lead to significant macroeconomic problems, i.e. financial instability. GDP growth rates have experienced substantial volatility in the previous period, but it could not be said that the BSS led to it. ${ }^{1}$

Due to some specifics of BSS and related regulations of the National Bank of Serbia (NBS), BSS was relatively better prepared for the impact of the global economic crisis than many other banking sectors of developed economies. BSS has managed in recent years to remain profitable (but last year's some banks recorded significant losses). Still, for keeping this trend in the future, it is required to respond to a number of challenges, such as the challenge of high credit risk in Serbia. What is related to this issue is the expectation of the economy from the BSS. In fact, now probably more than ever before, BSS need to give strong support to the strengthening of the economy and the sustainable economic growth of the country. BSS support to the Serbian economy is certainly significant, but the expectations of the economy are higher. For the economy which is due to the negative effects of the global economic crisis (again) fragile, strong financial support of the BSS is certainly necessary. It is important to say that the NBS during the previous period applied certain countercyclical measures during periods of economic expansion and recession. ${ }^{2}$ BSS was relatively highly capitalized in recent years, with a relatively high level of capital adequacy ratio (CAR), compared to the regulatory minimum of $12 \%$.

Total regulatory capital

Credit, market and operational risk

1 For more information see (Milojević and Dimitrijević, 2013)

2 For NBS countercyclical measures detailed analysis see (Milojević, 2011) 
Bearing in mind the aforesaid, issue of predicting the banking business trends in the future, as well as its impact on economic growth, should get adequate attention. The focus should be on determining of the optimal banking / financial business for achieving sustainable economic growth in Serbia. We can say that there is significant potential for moderate and balanced growth of the banking / financial business in the medium term, which could make a significant contribution to the achievement of sustainable economic growth in Serbia, while providing financial stability. For the realization of this important and demanding aim, it is necessary to meet a significant number of factors and creation of the adequate conditions at the micro and macro level, essential for achieving the above mentioned task. The success of this process could have many positive impacts on the economy and society in Serbia.

\section{Impact of financial intermediation on economic growth in the world}

The impact of the financial system on economic growth is attracting the attention of economists around the world, for centuries. During this long period, there were observed a number of positive and negative opinions about the impact of financial intermediation on economic growth. The economic crises which are also present for centuries, around the world, are particularly encouraging economist to constant revision of the established economic postulates. Similar trends exist today. After the effects of the global economic crisis, established postulates regarding the impact of financial development on economic growth, are (again) under review.

In this segment of the paper, we will review the development of economic thought and different conclusions regarding the impact of financial intermediation on economic growth in the world. Bagehot was in 1873, stressed the importance of the financial system for economic growth. He stated that the financial system has given positive contribution to the England's industrial development in the nineteenth century. One of the authors who left a significant contribution to the analysis of the financial system and economic growth relationship was Schumpeter (1911). He was also the inspiration for a number of authors and papers of this topic throughout the twentieth and twenty-first century. He emphasized that financial development is positive for the economic growth. Later we could see similar opinions with Goldsmith (1969), McKinnon (1973) and Shaw (1973).

On the other hand, Robinson (1952), claims that the economic growth creates demand for financial instruments, that the companies are leaders, while the fi- 
nancial system is following companies. Lucas (1988) pointed that the importance of the financial system for economic growth is overstated.

As for the further research of the late twentieth century and early twenty-first century, we could mention the following. King and Levine (1993) indicated that the degree of the financial intermediation development is a good indicator for predicting economic growth. Beck, Levine, and Loayza (2000) based on the empirical analysis conducted on a sample of a number of countries from the period 1960 - 1995, came to the conclusion that financial intermediation has a positive impact on productivity growth, as well as on overall economic growth. Beck (2008) has based on an analysis of 45 relevant countries (period 1994 - 2005) showed that loans to companies (as opposed to loans to households), give a boost to economic growth.

Analysis of the relation between the level of financial system development and economic growth in the world's leading economic circles, during the past decades, were primarily based on the developed countries experience.

On the other hand, in recent years, there are a significant number of analysis which refer to developing countries (from the perspective of Serbia this analysis are particularly interesting). One of these analysis (Koivu 2002), based on a sample of 25 developing countries and time series from the period in $1993-2000$ for determining quality of the banking sector is using the value of the interest margin on loans and deposits. Besides this indicator in this paper for level of financial sector development, is used an indicator of bank credit allocated to the private sector as a share of GDP. The conclusions are that a higher interest margin indicates lower economic growth, while on the other hand, credit growth does not accelerating economic growth.

Fink, Haiss and Mantler (2006) are based on analysis of nine countries which are preparing for accession to the EU or which recently become its members (some of them are countries in transition), came to the conclusion that overall financial development is accelerating economic growth.

Masten A.B. Coricellib and Masten I. (2008) analyzed the connection between the financial system and economic growth in 31 European countries. They came to the conclusion that the financial development in transition countries, more significantly contributes to economic growth, in comparison to the EU-15 countries, which have more developed financial systems and economies.

Regarding the most recent studies (ie. studies after the advent of the global economic crisis) of the financial intermediation impact on economic growth, we can 
say that some of the most interesting are the studies that attempt to reassess the established postulates, which need to be (again) reconsidered due to the effects of the global economic crisis. Bank for International Settlements (BIS) studies, related to this topic, were large and extensive. One of these papers represents paper from 2012, written by Cecchetti and Kharroubi.

Based on the survey, which took into account the characteristics of developed and developing countries, Cecchetti and Kharroubi have come to the conclusion that financial development is favorable for economic growth, to a certain level, after which it became an obstacle for further economic growth. The next conclusion is that the speed of the financial sector growth is very important for economic growth. Their opinion is that as the financial sector competes with the rest of the economy for scarce resources and that financial booms generally do not lead to a stronger economy (p. 14).

Cecchetti and Kharroubi stress that especially for the world's most developed financial sectors, is characteristic that, long time ago, they crossed the line of financial sector growth, where further growth, contributes to the general decline in productivity in the economy. If we bear in mind standard economic postulates that developed financial / banking system, reduces transaction costs, raising the

Figure 1: Credit allocated to the private sector as a share of GDP in developed countries at the end of year 2012

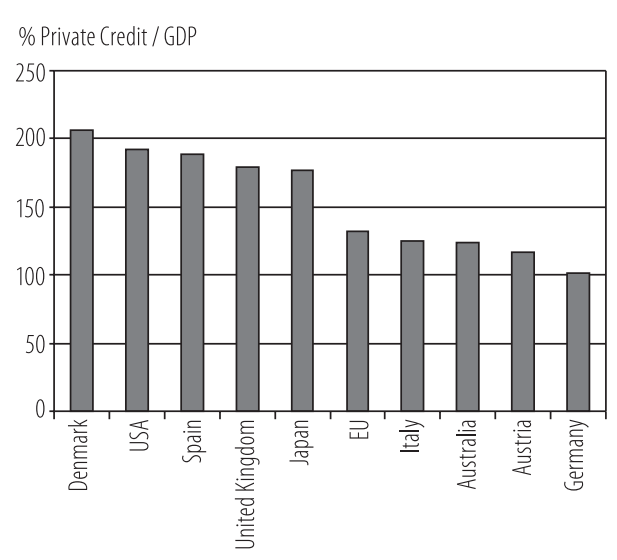

Source: Author, based on the World Bank data: http://data.worldbank.org/indicator/FS.AST. PRVT.GD.ZS/countries?display=default level of direct investment, improve the distribution of capital, generally leads to dispersion / risk reduction, previous Cecchetti and Kharroubi claims might be surprising. However, the financial sector competes with the rest of the economy, for the available resources. Under the resources we don't thinkt only on physical capital, but also on the best / most perspective employees. The result is that certain investments could be directed to the real sector, instead of in the financial sector. Also, people who could become top scientists and experts in the real sector / production, gave their contribution to the financial sector (Philippon and Reshef, 2009).

Cecchetti and Kharroubi, emphasize that before the global economic crisis, economy growth rates were high and 
supported by the financial sector. After the outbreak of the global economic crisis, it turned out that we had overinvestment. Many companies are not formed on the economically reasonable grounds, looking on the long-term. The same situation was with high employment unsustainable on the long run. Namely, these resources should have been directed to other industries and fields.

Cecchetti and Kharroubi analyzed data from 50 developed and developing countries over the past three decades. They used indicators private credit to GDP and the share of financial sector employment in the total employment as a measure for the size of the financial sector. They found that when the level of credit to the private sector exceeds the amount of GDP, the size of the financial sector becomes a burden for future economic growth. The maintenance of the credit to private sector/GDP ratio significantly below the level of $90 \%$, in cases of stress, makes it easier to fight tendencies that can lead to economic crisis. As an example of too big a financial sector that has become a burden for future economic growth, the authors mentioned some of developed countries such as the UK, Denmark and others, in which the aforementioned ratio approaches (or exceeds) $200 \%$. On the other hand, as a favorable position they stated the position of India. In India, the ratio of loans to GDP has been approaching $50 \%$ only in recent years and still provides enough leeway for further financial development, which can provide the impetus for sustainable economic growth.

The same conclusion that the size of the financial sector becomes a burden for a future economic growth has been stated in the case when the share of employees in the financial sector in the total employment exceeds 3.5\% (a sample for this analysis is limited to developed countries - Cecchetti and Kharroubi, 2012, p. 2). Also, based on the analysis of developed economies, they found that a sharp rise in employment in the financial sector, of 1.6 percentage points per year, reduces GDP growth by about 0.5 percentage points.
Figure 2: Credit allocated to the private sector as a share of GDP in developing countries at the end of year 2012

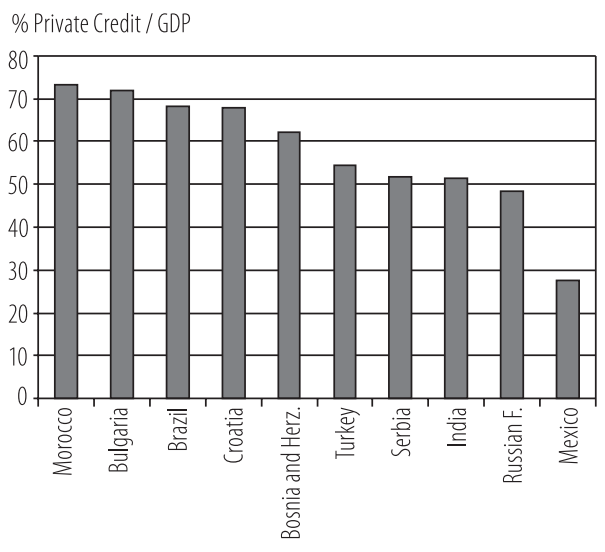

Source: Author, based on the World Bank data: http://data.worldbank.org/indicator/FS.AST. National Bank of Serbia: http://www.nbs.rs Statistical Office of the Republic of Serbia: http://webrzs.stat.gov.rs/axd/index.php

* For the Republic of Serbia, the total loans amount has been used. 
The aforementioned findings suggest the need to revise decades-old postulates regarding the optimal relation between the financial sector and economic growth. The lesson of the global economic crisis has led to the actualization of this question. Quick and efficient changes and adjustments of the relation financial system/real sector are needed. Simultaneously with the changes of this dynamic relationship, relevant regulation (primarily the financial system regulation) must be adjusted at the same pace.

\section{Development of the financial sector in Serbia}

The FSS has experienced significant development in comparison to the beginning of reforms initiated in 2000. However, despite the significant development, many segments of the FSS should make significant progress in order to approach the standards of highly developed countries, i.e. EU standards. The FSS is characterized by a pronounced domination of the banking sector, which accounts for $92.6 \%$ of the financial sector assets (as of 31.12.2012). The BSS has experienced the most significant development in the financial sector. Regarding a significant number of parameters, the BSS (this will be more discussed in the following part of this paper) is close to EU standards. The BSS is a segment of the FSS, which is most ready for EU integration.

Other financial institutions account for 7.5\% of the FSS assets. The insurance sector makes up $4.6 \%$, leasing companies $2.5 \%$ and pension funds $0.5 \%$ of the FSS assets.

Table 1: Structure of the financial sector in Serbia

\begin{tabular}{|c|c|c|c|c|c|c|}
\hline & \multicolumn{2}{|c|}{2010} & \multicolumn{2}{|c|}{2011} & \multicolumn{2}{|c|}{2012} \\
\hline & \multicolumn{2}{|c|}{ Assets } & \multicolumn{2}{|c|}{ Assets } & \multicolumn{2}{|c|}{ Assets } \\
\hline & $\begin{array}{l}\text { billion } \\
\text { RSD }\end{array}$ & $\%$ & $\begin{array}{l}\text { billion } \\
\text { RSD }\end{array}$ & $\%$ & $\begin{array}{l}\text { billion } \\
\text { RSD }\end{array}$ & $\%$ \\
\hline Financial sector & 2,759 & 100 & 2,868 & 100 & 3,108 & 100 \\
\hline Banking sector & 2,534 & 91.8 & 2,650 & 92.4 & 2,880 & 92.6 \\
\hline Other financial institutions & 226 & 8.2 & 218 & 7.6 & 228 & 7.4 \\
\hline Insurance sector & 117 & 4.2 & 126 & 4.4 & 140 & 4.5 \\
\hline Pension funds & 10 & 0.4 & 12 & 0.4 & 16 & 0.5 \\
\hline Leasing companies & 99 & 3.6 & 80 & 2.8 & 72 & 2.3 \\
\hline
\end{tabular}

Source: Author, based on the data from:

National Bank of Serbia (2013), Annual Financial Stability Report for 2012, Beograd, p. 64. 
The insurance sector is the second largest segment of the financial sector, with a share of $4.5 \%$. Although insurance companies have a long tradition in Serbia, the Serbian insurance sector is still relatively underdeveloped. Lagging behind the EU countries is significant, especially regarding the premium, which is one of the major indicators of the level of insurance development. We can say that some positive trends in the sector are visible. The sector is relatively well capitalized, but with low profitability, which would have to be higher so the sector could have a significant support for the maintenance of capital adequacy. The entering of foreign capital in the insurance sector brought about stronger competition. This should improve the quality of the sector and contribute to a further progress, for which certainly there is a significant potential.

The financial leasing sector represents, as seen by the size of assets, the third segment of the financial sector, with a share of $2.3 \%$. Over the past few years, the financial leasing sector, originally recorded high growth rates (period in 2005 2009), but leasing business stagnation has begun as of 2009 and is ongoing. Significant attraction of the financial lease instruments was characteristic for their first appearance in Serbia. At the same time, product portfolio of the financial sector has been significantly updated. Macroeconomic instability in recent years, accompanied by reduced liquidity of the economy and households, deterioration of their creditworthiness, a caution in borrowing, and other trends have had a negative impact on the performance of leasing institutions. The crisis has brought problems to the entire financial sector. It seems that in comparison to other financial institutions, leasing institutions (according to the rate of decline in the value of assets and other indicators), has experienced more problems with the latest crisis effects. The potential for further development of this sector in Serbia is certainly large, especially because it failed to develop fully before the advent of the global economic crisis.

Voluntary pension funds represent a segment of the financial sector which, with the share of $0.5 \%$ in the FSS, is significantly smaller than the first three aforementioned segments. Bearing in mind that voluntary pension funds have been established much later in relation to the EU, the backlog for the EU is understandable. A relatively low level of the financial market development contributes to the mentioned lagging behind. A further development of the financial market is one of the key preconditions for the development of voluntary pension funds. The development of the pension system is one of the particularly important strategic issues in Serbia.

Regarding the Broker - dealer companies and Investment funds management companies, we can say that most of the aforementioned factors that have had 
impact on voluntary pension funds are also characteristic for these companies. We primarily refer to a low level of development of the financial market and the impact of the global economic crisis. These are one of the main factors which stopped the initial development of the above mentioned companies and led to their stagnation. The capital market in Serbia is characterized by an increased level of risk. In order to create a stable and favourable business environment in the capital market and its faster growth, many regulations and harmonisations with international standards have been enacted. These trends certainly need to be continued, and an additional impetus to the capital market development is also needed.

One of the important characteristics of the financial market in Serbia is that it has a relatively small number of financial instruments with relatively low liquidity. An additional constraint to a further development of the financial market, and especially the capital market segment represents the insufficient number and level of development of domestic institutional investors. The capital market and other segments of the financial market should become a significant alternative to the banking sector in the future when it comes to financing the economy, as the latter remains dominate funding source of the economy. The role of the capital market and other segments of the financial market should become more important with the development of the economy. Highly developed economies and financial markets are characterized by the fact that the role of financing through the capital market and other segments of the financial markets is more significant in comparison to the importance of financial markets in developing countries.

Elements that will represent a challenge for the progress of the financial market in the future are the following: a reduction of concentration of ownership of companies listed on the Belgrade Stock Exchange, the strengthening of corporate governance, further development and improvement of the relevant regulations and standards, and the development of financial products that are generally underdeveloped, apart from some pioneer steps.

The FSS assets amounted to $91.8 \%$ of $\mathrm{GDP}^{3}$ at the end of 2012 . This data indicates that there is a considerable scope and potential for a further development of the FSS and support to a sustainable economic development. Taking into account presented recommendations and analysis of the relationship of the financial sector and economic growth to date, the FSS growth should be gradual and balanced, so the effects on sustainable economic growth would be adequate and bring about the financial stability maintenance. Further development of the FSS

\footnotetext{
3 National Bank of Serbia (2013), Annual Financial Stability Report for 2012, Beograd, p. 64.
} 
and the economy should bring a greater role of other financial institutions, in relation to their current role.

The share of the FSS employees in the total number of employees at the end of 2012 was $2.3 \%$. This is still substantially below the level of 3.5\%, which is in Cecchetti and Kharroubi study from 2012 (p. 2) marked as a level where further growth of the financial sector is beginning to negatively affect economic growth. However, it should be noted that the same study points out that even lower levels of the financial sector employees' share in total employment may be a burden for further economic growth. Particularly rapid growth of the share of employees in the financial sector may represent a burden to economic growth. The number of employees in the FSS has a variable trend. However, we can say that in the recent period it was stagnant, similarly to the total number of employees in Serbia.

Table 2: FSS share of employees in the total number of Republic of Serbia employees

\begin{tabular}{lcccc}
\hline & \multicolumn{2}{c}{31.12 .2012} & \multicolumn{2}{c}{30.6 .2013} \\
& in thousands & in \% & in thousands & in \% \\
\hline Republic of Serbia employees & 1.724 & 100.0 & 1.723 & 100 \\
\hline FSS employees & 39 & 2.3 & 38 & 2.2 \\
\hline BSS employees & 28 & 1.6 & 28 & 1.6 \\
\hline
\end{tabular}

Source: Author, based on the data from:

Statistical Office of the Republic of Serbia: $h t t p: / / w e b r z s . s t a t . g o v . r s / a x d / i n d e x . p h p$

National Bank of Serbia - Bank Supervision Department (2013), Banking Sector in Serbia Second Quarter Report 2013, Beograd

As already mentioned, the BSS is particularly dominant in the FSS. It is reasonable to expect that such domination will continue in the years to come (when we take into account the relevant circumstances in Serbia, as well as the global elements and external influences). Due to the above, the following analysis and projections of the impact of the FSS on economic growth in Serbia will primarily focus on the analysis related to the BSS. 


\section{Development of the banking sector in Serbia and impact on the economic growth}

The BSS has been prevalent in the FSS for many years. At the end of 2012, the BSS accounted for $92.6 \%$ of the financial sector assets. ${ }^{4}$ For these reasons, the central place in the study of the impact of the FSS on economic growth takes the BSS impact on economic growth of the country.

Analyzing the development of the BSS as of 2000 to date, we can conclude that there has been a significant progress, modernization, rapid growth and approaching to the international / European standards of banking business. Within the financial sector, banks have made the most significant progress.

Table 3: Development of the banking sector of the Serbia

\begin{tabular}{|c|c|c|c|c|c|}
\hline & \multicolumn{5}{|c|}{ Year } \\
\hline & 2008 & 2009 & 2010 & 2011 & 2012 \\
\hline Number of organizational units & 34 & 34 & 33 & 33 & 32 \\
\hline Number of organizational units & 2,711 & 2,635 & 2,487 & 2,383 & 2,243 \\
\hline Number of employees & 32,342 & 31,182 & 29,887 & 29,228 & 28,394 \\
\hline Market share of the foreign-owned banks (assets \%) & 75.3 & 74.3 & 73.5 & 74.2 & 75.1 \\
\hline Market share of the 5 biggest banks (assets $\%$ ) & 46.2 & 46.0 & 45.1 & 47.1 & 48.1 \\
\hline Assets (billion RSD) & $1,776.9$ & $2,160.4$ & $2,533.5$ & $2,649.9$ & $2,879.5$ \\
\hline Assets (billion EUR) & 20.1 & 22.5 & 24.0 & 25.1 & 27.3 \\
\hline Loans (billion RSD) & $1,027.6$ & $1,278.3$ & $1,685.4$ & $1,672.0$ & $1,752.1$ \\
\hline Loans (billion EUR) & 11.6 & 13.3 & 16.0 & 15.8 & 16.6 \\
\hline Deposits (billion RSD) & $1,024.7$ & $1,301.2$ & $1,504.8$ & $1,526.1$ & $1,698.5$ \\
\hline Deposits (billion EUR) & 11.6 & 13.6 & 14.3 & 14.5 & 16.1 \\
\hline Capital (billion RSD) & 419.9 & 447.5 & 498.0 & 545.9 & 591.1 \\
\hline Capital (billion EUR) & 4.7 & 4.7 & 4.7 & 5.2 & 5.6 \\
\hline Profit / loss (billion RSD) & 35.0 & 20.0 & 25.4 & 1.3 & 11.7 \\
\hline Profit / loss (million EUR) & 429.1 & 213.2 & 246.8 & 12.3 & 103.0 \\
\hline ROA - Return on Assets (\%) & 2.1 & 1.0 & 1.1 & 0.1 & 0.4 \\
\hline ROE - Return on Equity (\%) & 9.3 & 4.6 & 5.4 & 0.2 & 2.1 \\
\hline $\begin{array}{l}\text { The interest margin - difference between the average } \\
\text { weighted interest receivable and average weighted } \\
\text { interest payable (\%) }\end{array}$ & 7.5 & 6.7 & 6.1 & 5.9 & 5.4 \\
\hline Non-Performing Loans - NPL (total gross loans \%) & 11.3 & 15.7 & 16.9 & 19.0 & 18.6 \\
\hline Capital adequacy ratio - CAR\% & 21.9 & 21.4 & 19.9 & 19.1 & 19.9 \\
\hline
\end{tabular}

Source: Author, based on the data from: National Bank of Serbia, http://www.nbs.rs

4 National Bank of Serbia (2013), Annual Financial Stability Report for 2012, Beograd, p. 64. 
At the beginning of XXI century, reforms of the BSS (which was fragile like in the rest of the economy) has started. Reforms have entailed processes such as the following: the closing of a significant number of banks, restructuring and privatization, mergers and acquisitions, as well as the entry of foreign banks into the market.

The BSS had 86 banks at the beginning of the reform in 2001. Two years later, the number of banks almost halved. A downward trend in the number of banks continued in the following years, so the number of banks in Serbia at the end of 2012 amounted to 32. The structure of the BSS has also significantly changed compared to the beginning of reforms. The market share of foreign-owned banks (primarily from the EU) is constantly increasing, while the share of domestic state and private banks, declined. Although there has been a rapid growth in market share of foreign-owned banks, the competition in the BSS is very high, much higher than in many Central and Eastern Europe countries, that have gone (or are going) through the transition process.

Privatization and restructuring of banks in Serbia has completely changed the structure of the banking sector, but the bank balance sheet structure has also gone through some changes. The first half of the first decade of the XXI century was marked by banks assets, i.e. credit portfolio's recovery (but credit risk remained relatively high). Regarding liabilities and capital, we should mention the following: capital was refreshed with new equity investments, deposits increased, confidence in the banks savings was restored, and significant funds in the form of foreign credit lines arrived in Serbia.

On the other hand, the effects of the global economic crisis have had an inevitably negative impact on the BSS. Among others, the consequences at end of the last decade and the beginning of this are following: credit risk increase (NPL and other indicators of credit risk recorded deterioration), slowdown of credit growth, decline profitability, business network and employees downsizing, and other negative effects.

However, besides the abovementioned negative tendencies, compared with many European and other countries (especially compared with many developed countries), the BSS managed to solidly tackle with many negative effects of the global economic crisis. The CAR of the BSS recorded values above or around $20 \%$ for many years, i.e. significantly above the regulatory minimum of $12 \%$. At the end of 2012, the BSS CAR amounted to $19.9 \%$. During past few years, the big majority of the banks had a respectable value of the CAR, but there were few banks in same period with significant CAR problems. Today, credit risk remains high and 
most important risk in the BSS, but one of the important characteristics is that financial stability in Serbia is still satisfactory.

Table 4: Financial intermediation share in the Republic of Serbia's GDP

\begin{tabular}{|c|c|c|c|c|c|}
\hline & \multicolumn{5}{|c|}{ Year } \\
\hline & 2008 & 2009 & 2010 & 2011 & 2012 \\
\hline FSS assets to GDP (\%) & 74.7 & 87.4 & 95.7 & 89.4 & 91.8 \\
\hline BSS assets to GDP (\%) & 66.8 & 79.4 & 87.9 & 82.6 & 85.0 \\
\hline Total credit to GDP (\%) & 38.6 & 47.0 & 58.5 & 52.1 & 51.7 \\
\hline Corporate loans (without public companies) to GDP (\%) & 22.8 & 22.9 & 27.0 & 23.8 & 25.4 \\
\hline
\end{tabular}

Source: Author, based on the NBS data for BSS: (http://www.nbs.rs); Statistical Office of the Republic of Serbia, regarding data for GDP: http://webrzs.stat.gov.rs/axd/index.php

The current share of the BSS assets and loans in GDP, as compared to the period from the beginning of the reform in 2001, is significantly higher but still much lower compared to EU standards. On the other hand, the current value of financial intermediation does not indicate that the BSS is a burden for economic growth, and it leaves sufficient room for growth in the coming years.

The annual growth rate in lending activity in the period of 2006 - 2008, in real terms (corrected for the effect of the foreign exchange rate) amounted to $45.1 \%$ (domestic loans and corporate cross-border loans included). In the period of 2009 - 2012, the growth rate was $7.3 \%$ and at the end of 2012 it dropped to $1.5 \%{ }^{5}$

The BSS credit portfolio at end- 2012 amounted to 1.8 billion RSD. Regarding the portfolio structure, the situation is following: corporate loans (which traditionally dominate in the BSS portfolio) accounted for $55 \%$ of the credit portfolio. Net retail loans in the same period amounted to $30 \%$ of the credit portfolio.

Table 5: BSS and Republic of Serbia's GDP growth rates (nominal growth rates)

\begin{tabular}{lrrrrrrrrrr}
\hline & 2003 & 2004 & 2005 & 2006 & 2007 & 2008 & 2009 & 2010 & 2011 & 2012 \\
\hline GDP nominal growth rate (\%) & 15.8 & 22.6 & 21.9 & 16.5 & 16.0 & 16.9 & 2.2 & 5.9 & 11.3 & 5.5 \\
\hline BSS nominal growth rate (\%) & 16.1 & 40.6 & 50.0 & 50.8 & 33.6 & 13.8 & 21.6 & 17.3 & 4.6 & 8.7 \\
\hline $\begin{array}{l}\text { Share of the BSS assets growth in } \\
\text { the GDP growth (\%) }\end{array}$ & 102.0 & 179.6 & 228.1 & 306.9 & 209.2 & 81.6 & 978.5 & 290.3 & 40.5 & 156.6 \\
\hline
\end{tabular}

Source: Author, based on the NBS data for banking assets: (http://www.nbs.rs); Statistical Office of the Republic of Serbia, regarding data for GDP: http://webrzs.stat.gov.rs/axd/index.php

\footnotetext{
5 National Bank of Serbia (2013), Annual Financial Stability Report for 2012, Beograd, p. 55.
} 
In the table 5, we see that the growth of the BSS is generally faster than GDP growth (values in the table higher than $100 \%)$. In some years, the growth of the BSS significantly outpaced that of GDP (nearly 10 times in 2009).

Such a rapid growth of the BSS is quite understandable considering the back$\log$ that the entire Serbian economy had at the beginning of XXI century, in comparison to the other European countries in transition, which began reforms earlier and were not affected by sanctions, wars and economic crises during the 1990s. The BSS's relatively rapid growth in the past did not lead to significant macroeconomic problems or financial instability. GDP growth rates had significant fluctuations in the past, but it could not be said that the development of the BSS has led to that.

Due to some specific features of the BSS and related regulations of the NBS, the BSS was relatively better prepared for the impact of the global economic crisis than many other banking sectors in the world. The BSS has managed to remain profitable in recent years (but last year some banks recorded significant losses). Still, in order to keep this trend in the future, it is necessary to respond to a number of challenges, such as the challenge of high credit risk in Serbia. Related to this issue are the expectations of the economy from the BSS. In fact, now probably more than ever before, the BSS needs to give a strong support to the strengthening of the economy and a sustainable economic growth of the country. The BSS support to the Serbian economy was certainly significant, but the expectations of the economy are higher. For the economy which is left fragile due to negative effects of the global economic crisis (again), a strong financial support of the BSS is certainly necessary.

\section{Projections of the future development of the banking / financial business in Serbia and the impact on economic growth}

In this part of the paper, we are presenting some of the possible projections of further development of the banking / financial business in Serbia, taking into 
account the impact on economic growth, but also on financial stability and other important micro and macro parameters. Bearing in mind the presented BSS and country's current economic situation (and in the previous period), as well as the latest trends in the world and in Serbia, several projections are made in this research.

The baseline for expected economic growth in the coming years, we have used projections from the document of the Government of Republic of Serbia: “Fiskalna strategija za 2014. godinu sa projekcijama za 2015. i 2016. godinu" (p. 57). The mentioned document, among other things, shows the forecasts for GDP in the coming years, as shown in Table 6.

Table 6: Projections of the Republic of Serbia`s economic growth

\begin{tabular}{lrrrrrrrr}
\hline & 2013 & 2014 & 2015 & 2016 & 2017 & 2018 & 2019 & 2020 \\
\hline GDP simulation - real growth (\%) & 2.0 & 1.0 & 1.8 & 2.0 & 3.0 & 3.0 & 3.3 & 3.5 \\
\hline
\end{tabular}

Source: Vlada Republike Srbije (2013), Fiskalna strategija za 2014. godinu sa projekcijama za 2015. i 2016. godinu, Beograd, p. 57.

If we have in mind the displayed BSS characteristics and opportunities for further development, some of the possible projections of its future development, could be the following: we started from the assumption that the BSS growth gradually accelerates in comparison to GDP growth, but not to such a large level of acceleration, as we have seen in previous years. Here we have in mind that the BSS has to cope with the increasing NPL and many other challenges in the future. Support to the BSS growth, among other things, could be a solid capital base and the favourable situation in terms of leverage, which is not characteristic for many banking sectors in Europe.

Table 7: Projections of the Banking sector of Serbia growth

\begin{tabular}{lrrrrrrrr}
\hline & 2013 & 2014 & 2015 & 2016 & 2017 & 2018 & 2019 & 2020 \\
\hline BSS assets simulation - real growth (\%) & 2.0 & 1.3 & 2.8 & 3.8 & 6.0 & 6.5 & 7.3 & 7.7 \\
\hline
\end{tabular}

Source: Author

The above mentioned projections, could lead us to the following values for the ratio: "Banking sector of Serbia assets to GDP", which are shown in the following table. 
Table 8: Projections of the ratio movement "Banking sector of Serbia assets to GDP"

\begin{tabular}{lrrrrrrrr}
\hline & 2013 & 2014 & 2015 & 2016 & 2017 & 2018 & 2019 & 2020 \\
\hline Simulation: BSS assets to GDP (\%) & 85.0 & 85.3 & 86.1 & 87.6 & 90.2 & 93.3 & 96.9 & 100.8 \\
\hline
\end{tabular}

Source: Author

In the aforementioned projection, we see that the indicator "BSS assets to GDP" could exceed $100 \%$ in year 2020 . This would be still a moderate value compared with those in developed economies. We could call the presented projection for the indicator "BSS assets to GDP" the central or an orientation projection for this indicator. The ratio value might be lower if negative trends continue in the following years, such as NPL increase, negative external factors (continuation of the crisis in the EU, etc.), a significant decrease of foreign funding, etc. Also, a faster BSS growth could occur. However, this indicator will hardly exceed 110\% by 2020 . Even this value should still be moderate and balanced, which should not by itself represent a burden to the future economic growth of the country. Implementation of Basel III capital and liquidity standards (which is planned in Serbia), should be an additional support for preventing the banking sector excessive growth and preventing crises.

Regarding the FSS, the following assumption is applied: the FSS growth could be in the coming years, similar to the growth of BSS, or slightly lower (considering the trends in recent years in Serbia, and the expectation for the next period).

Table 9: Projections of the ratio movement "Financial sector of Serbia assets to GDP"

\begin{tabular}{lrrrrrrrr}
\hline & 2013 & 2014 & 2015 & 2016 & 2017 & 2018 & 2019 & 2020 \\
\hline Simulation: FSS assets to GDP (\%) & 91.8 & 92.1 & 93.0 & 94.6 & 97.4 & 100.7 & 104.6 & 108.8 \\
\hline
\end{tabular}

Source: Author

The next assumption is that an increase in loans in the years to come would be similar to the growth of assets. A part of the surplus liquid funds (part of investments in government securities), could gradually be reduced in favour of loans (due to simulated improved economic conditions in the country). In that case, the indicators "total credit to GDP" and "corporate loans (without public companies) to GDP" could have the following projected values. 
Table 10: Projections of the ratio movement "Total credit to GDP" and "Corporate loans (without public companies) to GDP" in the Republic of Serbia

\begin{tabular}{lrrrrrrrr}
\hline & 2013 & 2014 & 2015 & 2016 & 2017 & 2018 & 2019 & 2020 \\
\hline Simulation: BSS total credit real growth (\%) & 2.0 & 1.3 & 2.9 & 3.9 & 6.1 & 6.7 & 7.4 & 7.8 \\
\hline Simulation: total credit to GDP (\%) & 51.7 & 51.9 & 52.5 & 53.4 & 55.0 & 57.0 & 59.3 & 61.7 \\
\hline $\begin{array}{l}\text { Simulation: corporate loans } \\
\text { (without public companies) to GDP (\%) }\end{array}$ & 25.4 & 25.5 & 25.8 & 26.2 & 27.0 & 28.0 & 29.1 & 30.3 \\
\hline
\end{tabular}

Source: Author

We can say that the presented projected values of credit growth until 2020 are still at moderate levels, i.e. the levels which are not too high in relation to GDP, as is the case in some of advanced countries.

Taking into account conclusions from the current analysis in this paper, we can say that the projected BSS growth in assets and loans in the following years should not bring about excessive growth, which could be negative for the economy, create the conditions for an economic crisis, etc. (similar conclusion are valid for the FSS growth). On the contrary, this BSS growth should encourage sustainable economic growth while maintaining financial stability. It is necessary to mention that number of other internal and external factors (which are not the subject of detailed analysis in this study) might impact the achievement of these positive forecasts.

A gradual reduction of the interest margins would give a significant positive contribution to the achievement of the previous forecasts. There are indications and expectations that this could be achieved, but there are a lot of requirements that must be met such as the stabilization of economic situation in the country, in parallel with maintaining financial stability. A positive impact would also have an improvement of the credit rating of the Republic of Serbia, as well as the stabilization of economic situation in the region and the EU.

Regarding growth prospects of employment in the FSS / BSS (as support to the previous findings), we could say that they could have slightly better values in relation to possible future employment growth rate in the overall economy. The previous statement is valid if rising unemployment in Serbia could be stopped and turnover in trending could be achieved (like stated in the forecast in the document: Fiskalna strategija za 2014. godinu sa projekcijama za 2015. i 2016. godinu, p. 116). 


\section{Table 11: Projection of the FSS and BSS employees share in the total number of Republic of Serbia employees}

\begin{tabular}{lrrrrrrrr}
\hline & 2013 & 2014 & 2015 & 2016 & 2017 & 2018 & 2019 & 2020 \\
\hline $\begin{array}{l}\text { Simulation: FSS employees share in the } \\
\text { total number of R. Serbia employees }\end{array}$ & 2.2 & 2.2 & 2.2 & 2.3 & 2.3 & 2.3 & 2.4 & 2.4 \\
\hline $\begin{array}{l}\text { Simulation: BSS employees share in the } \\
\text { total number of R. Serbia employees }\end{array}$ & 1.6 & 1.6 & 1.6 & 1.6 & 1.7 & 1.7 & 1.7 & 1.8 \\
\hline
\end{tabular}

Source: Author

Like for the BSS growth rate, similar conclusions are valid for employment. Projected growth rate of the BSS employees share in the total number of employees is leaving space for sustainable economic growth. Also the projected values would still be significantly below the critical value, which has been mentioned at the beginning of the paper (Cecchetti and Kharroubi, 2012).

\section{Conclusion}

The effects of the global economic crisis are reinforcing the importance of determining the optimal scope and speed of financial intermediation growth. Excessive volume of financial intermediation and its speedy growth in many developed economies enhance negative effects of the crisis.

The FSS is characterized by a pronounced dominance of the banking sector, which is also the most developed segment of the FSS. The rest of the FSS: insurance sector, voluntary pension funds, financial leasing companies, broker - dealer companies and investment fund management companies have also made significant progress but still lag behind the BSS.

During the last decade and a half, the BSS growth usually outpaced that of GDP. In some years, the BSS growth was significantly faster (in 2009 nearly 10 times faster). We can say that the rapid growth of the BSS is quite understandable, having in mind the backlog of the entire Serbian economy at the beginning of XXI century, in comparison to other European countries in transition which had begun their reforms earlier and were not been affected by sanctions, wars and such strong economic crisis during 1990s. The analysis indicates that a relatively rapid growth of the BSS in the previous period did not lead to significant macroeconomic problems, i.e. financial instability. GDP growth rates experienced substantial volatility in the previous period but it could not be said that the BSS led to it. 
The share of financial development indicators in GDP: FSS assets (91.8\%), BSS assets (85.0\%) and BSS loans (51.7\%) in comparison with beginning of the reform from 2000s are significantly higher but still much lower compared to EU standards. On the other hand, the current value of financial intermediation does not indicate that the BSS or the FSS is a burden for economic growth and leave enough room for financial and economic growth in the coming years.

The analysis presented in this paper indicates that there is significant potential for a moderate and balanced growth of the banking and other financial business in the medium term, which could make a significant contribution to the achievement of sustainable economic growth in Serbia, while achieving financial stability. However, for the realization of this important and demanding goal, it is necessary to meet a significant number of factors, i.e. creation of essential adequate conditions at the micro and macro level for achieving the abovementioned objective.

Starting from the current GDP forecast in Serbia, as well as the BSS / FSS characteristics and opportunities for further development presented in the paper, several simulations have been conducted in the paper. We started from the assumption that the BSS growth gradually accelerate in comparison to GDP growth, but not to such a large level of acceleration as we have seen in previous years. Here we have in mind that the BSS has to cope with the increasing NPL and many other challenges in the future. Support to the BSS growth, among other things, could be a solid capital base and a favourable situation in terms of leverage.

The share of total BSS assets in GDP could exceed 100\% (amounted to 100.8\%) in year 2020. This would still be a moderate value compared to values in developed economies. The same indicator for the FSS could (according to the presented simulations) exceed $100 \%$ in 2018 . The share of total BSS loans in GDP could $61.7 \%$ in $r$ 2020. The share of corporate loans (excluding public enterprises) in GDP would amount to $30.3 \%$ in the same year. We can say that projected values of credit growth until 2020 are still at moderate levels, i.e. not too high in relation to GDP as is the case in some of the highly developed countries.

The projected growth in the BSS assets and loans in the following years should not bring about excessive growth, which could be negative for the economy, create the conditions for an economic crisis, etc. (similar conclusion are valid for the FSS growth). On the contrary, the simulated BSS/FSS growth should encourage a sustainable economic growth while maintaining financial stability. 
A gradual reduction of the interest margins would give a significant positive contribution to the achievement of the previous forecasts. There are indications and expectations that this could be achieved, but there are a lot of requirements that must be met such as the stabilization of economic situation in the country, in parallel with maintaining financial stability

Regarding growth perspectives of employment in the FSS / BSS (as support to the previous findings), we could say that they could have slightly better values in relation to a possible future employment growth rate in the overall economy. The previous statement is valid if rising unemployment in Serbia could be stopped and turnover in trending could be achieved. The share of FSS employees in the total number of employees in the Republic of Serbia could increase from the current $2.2 \%$ (1.6\% in the BSS) to $2.4(1.8 \%$ in the BSS) in 2020. 


\section{References:}

1. Bagehot, W. (1873 (1962 Edition)), Lombard Street: A Description of the Money Market, Homewood, IL: Richard D. Irwin

2. Beck, T. (2008), The Econometrics of Finance and Growth, World Bank, Policy Research Working Paper. No. 4608.

3. Beck, T., Demirguc-Kunt, A. and Maksimović, V. (2004), Bank Competition and Access to Finance: International Evidence, Journal of Money, Credit, and Banking, Vol. 36, No. 3, The Ohio State University Press

4. Beck, T., Levine, R. and Loayza, N. (2000), Finance and the Sources of Growth, Journal of Financial Economics 58, 261-300

5. Cecchetti S. G, and Kharroubi, E. (2012), Reassessing the Impact of Finance on Growth, Bank for International Settlements, BIS Working Papers No. 381

6. Festić, M. and Beko, J. (2008), The Banking Sector and Macroeconomic Performance in Central European Economies, Czech Journal of Economics and Finance, 58, 2008, no. 3-4, Praha

7. Fink, G., Haiss, P. and Mantler, H. C. (2005), The Finance-Growth Nexus: Market Economies vs. Transition Countries, University of Economics and Business Administration Vienna, Europainstitut Working Paper, No. 64.

8. Goldsmith, R. (1969), Financial Structure and Development, Yale University Press, New Haven

9. King, B. and Levine, R. (1993): Finance and Growth: Schumpeter Might be Right, Quarterly Journal of Economics, 108, 713-737.

10. Koivu, T. (2002), Do Efficient Banking Sectors Accelerate Economic Growth in Transition Countries?, Bank of Finland Institute for Economies in Transition, BOFIT Discussion Papers 14/2002

11. Lucas, R.E. Jr., (1988), On the Mechanics of Economic Development, Journal of Monetary Economics 22 (1): 3-42

12. Masten A.B. Coricellib, F. and Masten I. (2008), Non-linear Growth Effects of Financial Development: Does Financial Integration Matter", Journal of International Money and Finance, 27(2), 295-313.

13. McKinnon, R. (1973), Money and Capital in Economic Development, Brookings Institution, Washington DC

14. Milojevic N. (2011), Efekti primene Bazelskih standarda u Srbiji, Čugura print i Univerzitet Edukons, Beograd

15. Milojević, N. and Dimitrijević, B. (2013), Impact of the Serbian Banking Regulatory Framework Development on the Economic Growth of Serbia, Industrija, Vol.41, No.1, 2013, 33-58, Economic Institute, Beograd

16. National Bank of Serbia - Bank Supervision Department (2013), Banking Sector in Serbia - Second Quarter Report 2013, Beograd 
17. National Bank of Serbia (2013), Annual Financial Stability Report for 2012, Beograd

18. National Bank of Serbia, http://www.nbs.rs

19. Philippon, T and Reshef, A. (2009), Wages and Human Capital in the US Financial Industry: 1909-2006, National Bureau of Economic Research, NBER Working Papers, no 14644

20. Robinson, J. (1952), The Generalization of the General Theory, The Rate of Interest and Other Essays, Macmillan, London, 67-142.

21. Schumpeter, J. (1911), The Theory of Economic Development, Harvard University Press

22. Shaw, E. (1973), Financial Deepening and Economic Development, Oxford University Press, New York.

23. Statistical Office of the Republic of Serbia: http://webrzs.stat.gov.rs/axd/index.php

24. Vlada Republike Srbije (2013), Fiskalna strategija za 2014. godinu sa projekcijama za 2015. i 2016. godinu, Beograd

25. World Bank - http://data.worldbank.org/indicator/FS.AST.PRVT.GD.ZS/ countries?display $=$ default 